*Pós-doutorado em educação pela UFMG. Doutorado em direito pela PUC MINAS. Mestrado em direito pela PUC MINAS. Professor do programa de pós-graduação stricto sensu em proteção dos direitos fundamentais da Universidade de Itaúna.

E-mail: fvcufu@uol.com.br

**Juiz de Direito no Tribunal de Justiça de Minas Gerais. Mestrando em proteção dos Direitos Fundamentais pela Universidade de Itaúna. Especialista em direito público pela PUCMINAS

E-mail: alexmatososilva@gmail. com

***Mestre em direito pela PUCMINAS. Advogada. Professora da graduação em direito na pela Universidade de Itaúna.

E-mail: rosecipriano.adv@gmail. com

\section{Recurso extraordinário Como Modelo de Processo Coletivo}

\author{
Extraordinary Appeal As A Model For Class Action \\ LAWSUITS
}

\section{Fabrício Veiga Costa* \\ Alex Matoso Silva** Rosemary Cipriano da Silva***}

Como citar: COSTA, Fabrício Veiga; SILVA, Alex Matoso; SILVA, Rosemary Cipriano da. Recurso extraordinário como modelo de processo coletivo. Revista do Direito Público, Londrina, v. 14, n. 2, p. 91-108, ago. 2019. DOI: 10.5433/24157-108104-1.2019v14n2p. 91. ISSN: 1980-511X

Resumo: A Emenda Constitucional 45 instituiu a repercussão geral de questão constitucional como requisito de admissibilidade do recurso extraordinário. $\mathrm{O}$ recorrente deve demonstrar que a pretensão recursal transcende os interesses individuais das partes. Pretende-se demonstrar que a repercussão geral de questão constitucional é parte integrante do mérito da pretensão recursal, revisitando sua natureza jurídica de requisito de admissibilidade. O modelo de processo coletivo democrático participativo assegura a todos os interessados o direito de participar da construção do provimento. A análise da repercussão geral deverá ocorrer no âmbito da análise do mérito da pretensão recursal, legitimando a participação dialógica de todos os interessados na construção do provimento, para que o recurso extraordinário seja visto como um modelo de processo coletivo. Pela pesquisa bibliográfica e documental foram apresentadas proposições críticas acerca do tema pesquisado.

Palavras-Chave: Repercussão geral de questão constitucional. Mérito processual. Processo coletivo democrático. Recurso extraordinário. Requisito de admissibilidade.

Abstract: The Brazilian Constitutional Amendment 45 established 'general repercussion' as a constitutional requirement for the admissibility of any extraordinary appeal. Additionally, appellants must demonstrate that their appeal transcends individual interests. Furthermore, this study demonstrates that the general repercussion of a constitutional problem is of fundamental importance to appeals. Moreover, the participatory 
or collective democratic model ensures that all stakeholders have the right to participate in the foundation of any requisite of admissibility. Nonetheless, analysis of general repercussion should occur in the context of the analysis of the merits of the appeal, legitimizing dialogical participation of all interested parties in the construction of provisions, so that the extraordinary appeal is seen as a preferred model for democratic participation. This paper utilized literature review, whilst presenting critical examinations on the research topic.

Key words: General Repercussion of Constitutional Problems; Procedural merit; Democratic Collective Process; Extraordinary Appeal; Admissibility requirement. 


\section{INTRODUÇÃO}

O processo coletivo no Estado Democrático de Direito é o lócus que legitima a construção participada do provimento final por todos os interessados difusos e coletivos, ou seja, por todos os sujeitos com aptidão de sofrer direta ou indiretamente os efeitos jurídicos do conteúdo decisório.

O objetivo geral da presente pesquisa é demonstrar que a atual sistemática proposta pelo Recurso Extraordinário no Brasil adota a mesma estrutura teórica do modelo de processo coletivo, pois seu objeto versa sobre questões de cunho transindividual. A obrigatoriedade de demonstração prévia da repercussão geral de questão constitucional atribui ao recurso o caráter coletivo mencionado, evidenciado no efeito erga omnes e na impossibilidade de rediscussão do tema no âmbito nas instâncias ordinárias.

Sob o ponto de vista especifico pretende-se analisar criticamente a natureza jurídica da repercussão geral de questão constitucional, vista de forma dogmática como um requisito de admissibilidade, embora seja uma análise antecipada do mérito que integra a pretensão recursal, uma vez que ao recorrente cabe demonstrar o caráter transindividual daquilo que foi alegado.

É nesse cenário que temos a delimitação do objeto da pesquisa: se o pressuposto de admissibilidade do recurso extraordinário é a demonstração da repercussão geral de questão constitucional, é possível afirmar que tal recurso adota a mesma moldura teórico-científica do modelo de processo coletivo? Se os efeitos jurídicos do julgamento do mérito do recurso extraordinário são erga omnes, por que todos os sujeitos atingidos pelos efeitos do provimento final não são legitimados a participar da sua construção discursiva?

A justificativa da escolha do tema decorre da sua relevância teórica e prática, haja vista que a implementação do modelo constitucional de processo coletivo democrático passa diretamente pela legitimação de todos os interessados participarem processualmente da formação da vontade coletiva.

A atual sistemática adotada pelo Brasil no que atine ao recurso extraordinário exige do recorrente a coletivização da pretensão recursal como pressuposto de admissibilidade. Somente mediante a demonstração da relevância social, jurídica, política ou econômica do objeto do recurso é que se torna viável o julgamento do mérito. Trata-se de técnica processual utilizada como parâmetro para limitar o duplo grau de jurisdição e, assim, diminuir a quantidade de recursos julgados pelo Supremo Tribunal Federal.

Exigir do recorrente a demonstração prévia do caráter coletivo da pretensão recursal como pressuposto para o seu julgamento é impor o modelo de processo coletivo mediante a demonstração da existência de demandas de cunho metaindividual.

Nesse cenário, é importante ressignificarmos criticamente a repercussão geral de questão constitucional, com o objetivo de demonstrar que não se trata de mero requisito de admissibilidade, pois o que temos na realidade é um juízo de análise de mérito prévio ao julgamento do recurso proposto.

Todas essas indagações e proposições conduzirão o debate jurídico-constitucional do 
objeto da presente pesquisa, cujo propósito central é evidenciar a legitimidade democrática de todos os interessados difusos e coletivos na construção discursivo-participada do provimento final de mérito dos recursos extraordinários. A realização de audiências públicas é ferramenta essencial para garantir a democraticidade do provimento final, haja vista que através delas teríamos a possibilidade dos interessados participarem do debate e da construção do provimento meritório.

Metodologicamente utilizou-se da pesquisa teórico-bibliográfica, por meio de consulta a autores que debatem proposições necessárias ao estudo crítico-epistemológico do objeto de estudo ora proposto. A realização da pesquisa documental, através da consulta do texto da Constituição brasileira de 1988 foi essencial para robustecer o entendimento sistemático do recurso extraordinário como um espaço processual de debate de questões de natureza coletiva.

A realização de análises temáticas, teóricas, interpretativas e comparativas garantiu a compreensão do tema para além de proposições técnico-dogmáticas que limitam o exercício efetivo do duplo grau de jurisdição. Por meio do método dedutivo delimitou-se o objeto da pesquisa, partindo-se de uma concepção macroanalítica, qual seja, o estudo do recurso extraordinário, para investigar pontualmente a natureza jurídica da repercussão geral de questão constitucional como referencial lógico do modelo constitucional e democrático de processo coletivo participativo.

\section{GÊNESE E OBJETO DO RECURSO EXTRAORDINÁRIO: UM ESTUDO DO PROTAGONISMO JUDICIAL DOS MINISTROS DO STF}

Historicamente o recurso extraordinário tem sua gênese no writ of error dos ingleses, cuja finalidade era sanar erros de direito em favor da parte prejudicada. A influência do Direito Estadunidense também é significativa nesse contexto, tendo em vista que em 24 de setembro de 1789 foi criado o Judiciary act, que "visava preservar a supremacia da Constituição, e das leis federais, em suas aplicações pelos tribunais estaduais" (BORGES, c2012). Já no século XX, nos EUA, "a Emenda Regimental 3, de 12-06-1975, e a EC 7/77, inspiraram-se, portanto, no writ of certiorari, expediente equivalente a um filtro, responsável pela seleção de recursos cujas causas fossem detentoras de alguma relevância para provocar a atuação da Corte Suprema." (BARBOSA, 2008, p. 167).

O Supremo Tribunal Federal foi criado na Constituição Republicana de 1891, que em seu artigo 59 disciplinou de forma clara acerca da competência originária (inciso I) e recursal (inciso II). Em 16 de julho de 1934 entrou em vigor no Brasil a segunda Constituição Republicana, que ao Supremo Tribunal Federal deu a denominação de Corte Suprema. A Constituição brasileira de 1937 devolveu ao Pretório Excelso novamente o nome de Supremo Tribunal Federal, instituindo em seu artigo 101 a competência originária e recursal. As Cartas de 1946, 1967 e 1969, seguindo a esteira das constituições anteriores, mantiveram a competência originária e derivada do Supremo Tribunal Federal (BORGES, c2012).

A Constituição brasileira de 1988 trouxe expressamente em seu artigo 102, inciso III, a competência do Supremo Tribunal Federal para o julgamento do Recurso Extraordinário. 
Evidencia-se que a nova ordem constitucional democrática confere ao Supremo Tribunal Federal a competência de guardião da Constituição, cabendo-lhe a preservação e a interpretação de normas constitucionais, uniformização da jurisprudência nacional por meio do controle abstrato de constitucionalidade e controle difuso, este último concretizado por meio do julgamento do recurso extraordinário, cujo propósito é assegurar inteireza do sistema jurídico vigente.

As alíneas “a, b, c, e d" do inciso III, artigo 102, da Constituição brasileira de 1988, traz as hipóteses de cabimento do recurso extraordinário: decisões que contrariam dispositivo constitucional; decisões que declaram a inconstitucionalidade de tratado ou lei federal; decisões que julgam válida lei ou ato de governo local contestado em face da Constituição; decisões que julgam válida lei local contestada em face de lei federal (OZAKI, 2010).

O legislador constituinte foi claro, objetivo e assertivo ao instituir as hipóteses restritivas de cabimento do recurso extraordinário. Atribuiu-se ao Supremo Tribunal Federal, no âmbito do exercício da competência derivada, a legitimidade pressuposta de direcionar a interpretação constitucional do ordenamento jurídico brasileiro, sanando divergências interpretativas em busca da maior segurança jurídica.

Observa-se que o legislador brasileiro conferiu aos ministros do Supremo Tribunal Federal a autolegitimação de interpretar solitariamente o texto constitucional, estendendo-se os efeitos jurídicos de suas interpretações à sociedade em geral, de forma vinculativa, sem permitir a esses destinatários do provimento final o direito de participarem discursivamente do debate meritório das questões atinentes aos seus interesses. A sistematização jurídica das competências do Supremo Tribunal Federal, especialmente no julgamento dos recursos extraordinários, reproduz um modelo de processo autocrático, em que o julgador é visto como a boca de lei. O protagonismo e a discricionariedade judicial, carregados da metajuridicidade advinda dos juízos axiológicos, direcionam o julgamento do mérito das pretensões recursais.

Os destinatários do provimento meritório ficam alheios ao debate processual, embora sofram diretamente os efeitos jurídicos daquilo que foi solitariamente deliberado pelos ministros. No exercício da jurisdição o juiz é soberano; "não há nada que se sobreponha ao juiz, nem a própria lei” (STRECK, 2012, p. 35). Mauro Cappelletti (1993, p. 31-33), em sua obra “Juizes Legisladores?”, enfatiza que a criatividade no exercício da função jurisdicional constitui um fenômeno típico de nosso século, ressaltando-se que escolhas no ato de decidir significa discricionariedade, embora não necessariamente arbitrariedades.

No exercício de sua função jurisdicional, especificamente no que atine ao julgamento do mérito dos recursos extraordinários, os ministros do Supremo Tribunal Federal decidem de forma soberana e solitária, já que são protagonistas do decisionismo judicial. Pautados numa racionalidade pressuposta, advinda de percepções muitas vezes sensitivas, os julgadores definem os rumos da ciência do Direito e das pessoas, sem sequer consultá-las. Autolegitimam-se os senhores da lei, os criadores do Direito, que no entendimento de Luis Recaséns Siche, citado por Lídia Reis de Almeida Prado, “[...] na produção do julgado, destaca-se o papel do sentimento do juiz, cuja importância fica evidenciada pela etimologia da palavra sentença, que vem de sentire, 
isto é, experimentar uma emoção, uma intuição emocional.” (PRADO, 2010, p. 18).

A intuição como critério regente das decisões judiciais traz no seu bojo a significação de que o jurisdicionado encontra-se em absoluta condição de subserviência ao subjetivismo, solipsismo e juízos axiológicos do julgador. Nesse mesmo sentido, Joaquim Dualde afirma que “[...] torna-se necessário que o juiz utilize a sensibilidade e a intuição como método de penetrar na realidade, corrigindo as desfigurações advindas da busca do conhecimento através de conceitos." (PRADO, 2010, p. 19). Tais entendimentos perpetrados pelos estudiosos ora mencionados denotam claramente que os julgadores são vistos como pessoas pressupostamente dotadas de uma sabedoria inata, de natureza divino-sacerdotal, com a responsabilidade de assegurar às partes uma decisão justa, produto de seu sentimento e subjetividade. Seriam os magistrados pessoas escolhidas por entidades míticas para fazer valer a justiça entre os homens?

No Brasil, o jurista Miguel Reale, ao propor sua Teoria Tridimensional do Direito, enfatiza a necessidade da humanidade do juiz na implementação da justiça, uma vez que os juízos valorativos (subjetividade do julgador) devem ser vistos como os referenciais lógicos do magistrado no ato de julgar (PRADO, 2010, p. 22-23).

Esses autores certamente contribuem para a mitologização da figura do juiz como entidade divinizada, sacralizada e garantidora da justiça pressuposta aos jurisdicionados, reforçando substancialmente a autoridade e a autocracia daquele sujeito responsável pela decisão.

As críticas ao protagonismo judicial são fundamentais à investigação do objeto da presente pesquisa. No Brasil, a sistemática adotada quanto ao recurso extraordinário, reforça a clássica concepção de que o processo é o espaço em que o julgador faz prevalecer sua autoridade diante do julgamento do caso concreto, ignorando, muitas vezes, as alegações apresentadas pelas partes.

O modelo de processo adotado no estudo do recurso extraordinário no Brasil reproduz a autocracia judicial, o decisionismo, o solipsismo, a discricionariedade do decididor. As partes que sofrem diretamente os efeitos do provimento ficam alheias do debate processual do mérito, embora sejam por eles diretamente atingidas. Afastar ou impedir que as partes integrem o debate processual do mérito da pretensão recursal, mediante a realização de audiências públicas, é restringir o debate das questões meritórias, concentrando-se a decisão exclusivamente nas mãos dos julgadores, além de comprometer a legitimidade democrática do provimento.

Em contrapartida, o processo coletivo democrático-constitucional, pautado no modelo participativo, elastece e amplia o espaço processual, oportunizando a todos os sujeitos interessados a participação no debate as questões controversas que integram o mérito da demanda. A partir dessas novas proposições teóricas, pretende-se revisitar criticamente o atual sistema que rege o recurso extraordinário no Brasil, de modo a viabilizar maior democraticidade dos provimentos jurisdicionais.

\section{PROCESSO COLETIVO DEMOCRÁTICO E MODELO PARTICIPATIVO}

A constitucionalização no estudo do processo, visto como lócus de discursividade ampla 
das questões controversas que integram a demanda é o referencial teórico para o estudo critico do objeto da respectiva pesquisa.

O princípio da supremacia da Constituição emerge como garantia fundamental do devido processo constitucional (DIAS, 2010, p. 82), ressaltando-se que a teoria constitucional do direito democrático somente será compreensível se fundada nas bases legitimantes da cidadania e soberania popular (LEAL, 2009, p. 86).

O processo constitucional democrático é um contraponto ao modelo autocrático de processo adotado no julgamento do recurso extraordinário no Brasil. O protagonismo judicial é revisitado por proposições teóricas que compreendem o processo como um espaço de debate amplo das questões controversas pelos interessados no provimento. Os princípios do contraditório, da ampla defesa, devido processo legal e isonomia processual regem a estrutura procedimental do debate da pretensão no âmbito processual pelas partes interessadas.

“O contraditório deixa de ser mero atributo do processo e passa à condição de principio (norma) determinativo da própria inserção na estruturação de todos os procedimentos preparatórios dos atos jurisdicionais" (LEAL, 2002a, p. 8). O contraditório não se limita à idéia de um mero dizer e contradizer; trata-se da igualdade jurídica de oportunidade de argumentação conferida às partes, ou seja, é a liberdade de poder debater os pontos controvertidos e vê-los apreciados pelo magistrado no julgamento do mérito.

A construção participada do provimento jurisdicional no Estado Democrático de Direito não é garantida apenas com a mera oportunização do debate meritório às partes interessadas; é necessário que o julgador se manifeste, de forma juridicamente racional, sobre as questões debatidas pelas partes no ato de decidir. Se o magistrado ignorar o que foi alegado pelas partes no âmbito processual, mesmo tendo garantido o direito de debate, não assegurará a legitimidade democrático-discursiva do provimento final. "O dever de fundamentar as decisões consiste em garantia da parte em obter resposta as suas alegações, o que demonstra estreita correlação da garantia da fundamentação das decisões com o contraditório.” (FREITAS, 2014, p. 32).

"O processo na Teoria do direito democrático é o ponto discursivo da igualdade dos diferentes." (LEAL, 2002b, p. 75). É no âmbito processual que se deve assegurar às partes interessadas o efetivo direito de argumentar, participar e garantir a co-autoria de decisões que irradiam efeitos jurídicos diretos ou indiretos na esfera individual ou coletiva de cada sujeito. É “oportunizar a discussão de todos os interessados, garantindo-se a construção de um espaço procedimentalizado em contraditório, a fim de afastar protagonismos e a busca solitária pela aplicação do direito com justiça." (PAOLINELLI, 2014, p. 52).

Aargumentação processual pelas partes interessadas no provimento consiste em implementar a igual oportunidade de interpretação da lei a todos, ou seja, "erige ao julgador vedação a recursos interpretativos extrassistêmicos." (GRESTA, 2014, p. 191).

É nesse contexto argumentativo que advém os estudos do processo coletivo democrático no modelo participativo. A democracia é um paradigma de Estado que preconiza o exercício amplo das liberdades dos cidadãos orientarem-se por meio da participação nos processos deliberativos dos 
quais resultam decisões que poderão afetar toda a coletividade. A autodeterminação democrática é corolário do exercício da cidadania pelo princípio participativo.

Os espaços de interlocução buscam a formação de opiniões dos cidadãos por meio de redes de discussões que visam construir o consenso coletivo e a gestão dos dissensos, oferecendo subsídios, conteúdos e critérios para deliberações participadamente tomadas e que venham a atender o interesse da coletividade.

O processo coletivo no modelo participativo deve ser resultado da compreensão procedimental e discursiva dos direitos coletivos e difusos, no contexto da participação dos sujeitos interessados como agentes da formação da vontade democrática. A formação democrática da vontade decorre da convergência dos melhores argumentos apresentados ao debate no processo deliberativo. No espaço processual onde se desenvolverá o discurso democrático da pretensão coletiva nunca deverá prevalecer vontades individuais em detrimento dos direitos transindividuais. A própria finalidade e utilidade do discurso democrático é o amadurecimento das questões de mérito que conduzirão todo debate instaurado entre os legitimados ao provimento.

"O processo coletivo brasileiro deve ser estudado segundo os moldes instituídos a partir de 1988 e nesse sentido pautar-se na construção de normas procedimentais que o regerão." (FERREIRA, 2016, p. 129). Considera-se coletivo o modelo de processo cujo objeto de discussão são pretensões que ultrapassam a esfera individual. São aquelas pretensões de relevante discussão jurídica, política, social ou econômica, que afetam um número indeterminado e pessoas.

A atual estrutura procedimental do recurso extraordinário no Brasil preconiza o debate de questões que não sejam de cunho eminentemente privado; individual. O pressuposto para a análise do mérito da pretensão recursal é que seu objeto verse sobre um tema de relevância para a sociedade brasileira ou um número indeterminado de pessoas. A implementação dessa sistemática ocorreu com o advento da repercussão geral de questão constitucional, decorrente da aprovação da Emenda Constitucional 45/2004.

Nesse contexto, é perfeitamente possível afirmar que o recurso extraordinário brasileiro é um espaço de deliberação de questões coletivas. Por isso, garantir a participação dos interessados difusos e coletivos no debate das questões de mérito é condição da legitimidade democrática do provimento. Concentrar a decisão dessas questões apenas nas mãos dos ministros do STF é retirar dos indivíduos o direito de exercício da cidadania; é uma forma de atentar contra a soberania popular, considerada um dos fundamentos da República Federativa do Brasil (artigo $1^{\mathrm{o}}$, parágrafo único da Constituição de 1988) (BRASIL, [2016]).

\section{REPERCUSSÃO GERAL DE QUESTÃO CONSTITUCIONAL COMO REQUISITO DE ADMISSIBILIDADE DO RECURSO EXTRAORDINÁRIO}

A repercussão geral de questão constitucional foi inspirada no writ of certiorar (KOSZUOSKI; PENACHIONI, 2010) de juízo de relevância do Tribunal Constitucional, da Suprema Corte norte-americana. Insta destacar que a relevância das questões postas em julgamento 
pelas Cortes Constitucionais já estão previamente definidas, o que não acontece no Brasil, uma vez que a norma constitucional não define de forma exata o que vem a ser a repercussão geral, concentrando-se nas mãos dos membros do STF a legitimidade para interpretação jurídica de tal instituto.

A Emenda Constitucional 45, de 06 de dezembro de 2004, denominada de Reforma do Judiciário, instituiu no $\S 3^{\circ}$, do artigo 102, a repercussão geral de questão constitucional. O motivo determinante que justifica tal alteração legislativa foi a crise do recurso extraordinário vivenciada pelo Supremo Tribunal Federal, que caracteriza na realidade a intenção de limitar o duplo grau de jurisdição e diminuir o número de recursos a serem julgados na instância extraordinária.

O $\S 3^{\circ}$, do artigo 102 da Constituição de 1988, é uma norma jurídica de aplicabilidade limitada, que necessita de norma infraconstitucional para regulamentá-la. O conteúdo genérico e amplo trouxe para o texto constitucional um conceito aberto e indeterminado, cuja interpretação concentrava-se na criatividade do julgador. Por isso, em 20 de dezembro de 2006 foi publicada a Lei 11.418, criada especificamente com o objetivo de esclarecer para os juristas como interpretar e compreender racionalmente o respectivo instituto.

A norma infraconstitucional novamente trouxe um conceito aberto e indeterminado ao estabelecer que a repercussão geral caracteriza-se por ser aquelas pretensões nas quais o recorrente comprovadamente demonstra sua relevância jurídica, social, econômica ou política. Continuou concentrada nas mãos dos ministros do STF decidirem casuisticamente qual recurso extraordinário possui ou não repercussão geral.

Considerando-se que a repercussão geral de questão constitucional foi categorizada pelo direito brasileiro como um requisito de admissibilidade (WAMBIER; TALAMINI, 2010, p. 715)', verifica-se que o conhecimento ou não do recurso extraordinário ficará ao alvedrio do julgador, que de forma solitária e solipsista decidirá se o recorrente preencheu ou não o respectivo pressuposto de admissibilidade. Na realidade, "o dispositivo da repercussão geral possibilita que o Supremo Tribunal Federal escolha os recursos extraordinários que irão julgar, levando em consideração a relevância econômica, social, política ou jurídica da matéria a ser apreciada.” (KOSZUOSKI; PENACHIONI, 2010).

A implementação da repercussão geral no Brasil constitui uma forma subjetiva de analisar a admissibilidade do recurso extraordinário, colocando o recorrente e a sociedade civil absolutamente refém do julgador, que no âmbito de sua sabedoria oracular, por interesses pessoais, posicionamentos político, morais, religiosos poderá entender que inexiste tal pressuposto de admissibilidade em determinado caso de relevante envergadura e interesse da coletividade.

A indefinição jurídica de um conceito aberto no direito legitima a autocracia jurisdicional; fortalece a jurisdição sacerdotal; confere ao julgador uma legitimidade pressuposta para decidir solitariamente o que é de interesse da sociedade, sem ter a necessidade de consultar ou debater com os sujeitos interessados as questões que versam diretamente sobre seus direitos. Os indivíduos

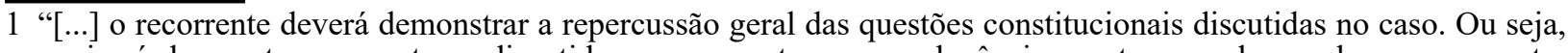
precisará demonstrar que o tema discutido no recurso tem uma relevância que transcende aquele caso concreto, revestindo-se de interesse geral, institucional (WAMBIER; TALAMINI, 2010, p. 715). 
que sofrerão diretamente os efeitos do provimento final simplesmente ficam alheios e distantes do espaço processual onde se debate (ou não) as questões de cunho metaindividual.

A inclusão de tal técnica procedimental no ordenamento jurídico brasileiro reproduz mais uma vez o modelo autocrático de processo, centrado no decisionismo judicial. A limitação do direito fundamental de ampla argumentação fática e jurídico-legal da pretensão pelos seus interessados é um fenômeno que caracteriza o exercício da jurisdição no âmbito extraordinário. O contraditório é suprimido no momento em que se retira do jurisdicionado a possibilidade de participação efetiva na construção do provimento. Mesmo assim, esse jurisdicionado que teve tolhido o direito de argumentar discursivamente as questões controversas do mérito processual, sofrerá os efeitos jurídicos do conteúdo decisório.

A eficácia horizontal e vertical decorrente do caráter erga omnes e vinculante são características ínsitas das decisões de mérito proferidas no julgamento do recurso extraordinário. A segurança jurídica, economia dos atos processuais e a maior estabilidade das decisões são os argumentos frequentemente utilizados pelos defensores da repercussão geral. $\mathrm{O}$ dogma da celeridade processual também é uma justificativa para não ampliar a participação popular no julgamento dos recursos extraordinários no Brasil.

Com o objetivo de minimizar e amenizar o problema crônico da morosidade judiciária enfrentado pelo jurisdicionado no Brasil o legislador pátrio, de forma absolutamente hermética e dogmática, deflagrou uma seqüência de alterações legislativas no sentido de buscar maior celeridade, efetividade e economicidade processual, oferecendo aos cidadãos uma resolução mais rápida de seus conflitos de interesses. A criação da repercussão geral de questão constitucional é um exemplo que ilustra a intenção do legislador em dar uma resposta ideológica ao cidadão que busca maior agilidade na resolução dos conflitos de interesses.

A compreensão cronológica do principio da celeridade processual, a busca incessante pela efetividade e o claro fetiche pela economia processual são estratégias sutis utilizadas pelo legislador para suprimir direitos, limitar o acesso legitimo ao Judiciário, desencadear o cerceamento de defesa e, acima de tudo, impossibilitar a discussão dos fundamentos e das questões de ordem fática e jurídicas que integram o mérito da pretensão deduzida pelos seus interessados.

A crítica cientifica proposta na presente pesquisa versa sobre os seguintes questionamentos: por que o legislador excluiu o cidadão do debate amplo das questões coletivas no âmbito processual? Por que a repercussão geral de questão constitucional é definida e debatida com exclusividade entre os julgadores, sem permitir a participação dos interessados no debate processual?

A primeira constatação a partir das indagações suscitadas é que no Brasil adotamos um modelo de processo que não privilegia a participação dos interessados na construção do provimento. Isso evidencia que o sistema participativo, constitucionalmente previsto, é uma realidade obscura e apenas instituída no plano das proposições teóricas.

Outra constatação relevante é que o processo brasileiro é visto e compreendido sob a ótica do tempo cronológico, ou seja, nosso legislador acredita que utilizando-se das técnicas de sumarização da cognitio e limitação do espaço processual de argumentação conseguirá oferecer ao 
jurisdicionado decisões mais céleres. Ignora que os principais motivos que explicam a morosidade judicial no Brasil são o tempo morto do processo (o tempo que o processo fica parado nos gabinetes dos magistrados e nas secretarias dos juízos) e o excesso de litigiosidade decorrente das constantes violações de direitos fundamentais praticadas pelo Estado em prejuízo do cidadão. Tal concepção nada mais é do que uma ideologia utilizada para justificar a não implementação do modelo constitucional de processo democrático, cujo objetivo precípuo é a garantia do amplo espaço processual argumentativo oferecido a todos os interessados no provimento jurisdicional.

Oportunizar a todos os interessados difusos e coletivos o direito de se manifestarem e debaterem (de forma ordenada) o mérito da pretensão não comprometerá o deslinde célere das pretensões judiciais. O cumprimento rigoroso dos prazos processuais próprios e impróprios e a superação do tempo morto do processo certamente garantirão ao cidadão uma prestação jurisdicional mais célere.

\subsection{Releitura Crítica da Repercussão Geral Como Juízo Pré-Meritório}

Nos termos dispostos no artigo $102, \S 3^{\circ}$ da Constituição brasileira de 1988 e na Lei 11.418/2006, a repercussão geral de questão constitucional é um requisito de admissibilidade do recurso extraordinário. Ao recorrente incumbirá o dever de demonstrar que a pretensão recursal transcende o caso concreto, ou seja, que se reveste de interesse geral, institucional, coletivo, social, político, jurídico ou econômico.

Trata-se de técnica processual que exige que o recorrente coletivize sua pretensão recursal, mesmo que seja originariamente individual. Caberá a quem propuser o recurso extraordinário demonstrar que além da envergadura constitucional a ser debatida, o objeto do recurso estendese a um numero indeterminado de pessoas, à toda sociedade civil ou a um determinado grupo de pessoas interessadas juridicamente no debate do tema.

A primeira indagação levantada nesse contexto é a seguinte: a atual sistemática processual limita o exercício do duplo grau de jurisdição? Ao exigir do jurisdicionado a coletivização de sua pretensão inicial como requisito imprescindível à análise do mérito o legislador reconhece que pretensões relevantes constitucionalmente, mas que não possuem dimensão coletiva, ficarão afastadas da possibilidade de serem debatidas e julgadas via recurso extraordinário. O Supremo Tribunal Federal perderá a oportunidade de debater questões de relevância constitucional quando o recorrente não demonstrar a transcendência do seu caso concreto ou quando não ficar claro quais outras pessoas além do jurisdicionado poderão ser afetadas pela discussão meritória.

É sabido que no direito brasileiro considera-se evidente a repercussão geral de questão constitucional naquelas pretensões que estampam claramente sua relevância jurídica, social, política ou econômica. Nesse cenário, oportuno o levantamento de outra aporia: há alguma contradição nos textos legislativos no momento em que define o que é repercussão geral de questão constitucional e ao mesmo tempo a classifica como um requisito de admissibilidade do recurso extraordinário? Certamente sim, pois esse é um dos pontos nevrálgicos da presente pesquisa. 
Considera-se requisito ou pressuposto de admissibilidade recursal as questões formais, extrínsecas ao mérito e consideradas procedimentalmente indispensáveis ao julgamento do mérito. A tempestividade, adequação, cabimento, regularidade formal, sucumbência, legitimidade para recorrer, preparo, esgotamento das instâncias ordinárias e o prequestionamento são alguns exemplos que ilustram bem que a noção teórica construída no direito brasileiro é que pressuposto de admissibilidade recursal são elementos que procedimentalizam o julgamento do mérito, mas com ele não se confunde.

Nesse cenário, indaga-se: a repercussão geral de questão constitucional é uma questão decorrente da técnica-procedimental ou integra o conteúdo meritório do recurso extraordinário? No momento em que o legislador exige do recorrente a demonstração da relevância jurídica, econômica, política ou social da pretensão recursal antecipa a análise do conteúdo de direito que integra o mérito da pretensão recursal. Teríamos, nesse contexto, um juízo pré-meritório, categorizado erroneamente pelo legislador pátrio como um requisito de admissibilidade.

No direito processual brasileiro o mérito pode ser compreendido como todas as matérias de fato e de direito que integram as questões controversas da demanda. Considera-se questão de fato a análise de provas necessárias a evidenciar fatos alegados em juízo, ou seja, reexame de provas configura matéria fática para fins processuais. Já a matéria de direito consiste na argumentação jurídico-constitucional e legal racionalmente construída a partir da interpretação sistemática do caso concreto. No recurso extraordinário admite-se apenas a alegação de matéria de direito, ou seja, o objeto do debate meritório na instância extraordinária consiste na análise pormenorizada do direito a ser aplicado ao caso concreto; da forma mais adequada e racional de interpretação do texto constitucional; do entendimento dialógico das normas infraconstitucionais interpretadas conforme a Constituição brasileira de 1988.

A repercussão geral de questão constitucional é parte integrante da matéria de direito alegada no recurso extraordinário. Trata-se da necessidade do recorrente demonstrar que a matéria de direito suscitada transcende o caso concreto, é de interesse coletivo, difuso, que integra o patrimônio material ou imaterial de um grupo ou número indeterminado de pessoas; que não se restringe aos interesses individuais das partes que integram a relação processual originária; que se trata de pretensão recursal de cunho metaindividual.

A análise prévia da transindividualização da pretensão recursal, vista como requisito de admissibilidade do recurso extraordinário constitui clara contradição no sistema jurídico brasileiro vigente. Verificar se a matéria de direito suscitada no recurso proposto ultrapassa a esfera individual e exigir do jurisdicionado sua demonstração prévia é uma forma de antecipar a discussão e a análise do mérito, até porque atualmente o Supremo Tribunal Federal não goza de legitimidade de análise de pretensões recursais relevantes constitucionalmente, mas que não tenham dimensão transindividual.

A repercussão geral de questão constitucional não pode ser vista como uma questão meramente técnica, alheia ao mérito processual, adstrita ao formalismo procedimental. Todo elemento ou instituto que se encontra à margem do mérito processual não se relaciona com as 
questões de fato e de direito que integram a pretensão. Um recente exemplo de questão que foi por muito tempo considerada equivocadamente extrínseca ao mérito é a possibilidade jurídica do pedido, que com o advento do Novo Código de Processo Civil deixou de ser hipótese ensejadora de sentença terminativa. No mesmo sentido encontra-se a repercussão geral, considerada atecnicamente como um pressuposto formal de admissibilidade do recurso, certamente com o condão de limitar o acesso ao Supremo Tribunal Federal no exercício da competência derivada e restringir o exercício amplo e legítimo do duplo grau de jurisdição a todos os interessados e comprovadamente sucumbentes.

\section{RECURSO EXTRAORDINÁRIO COMO MODELO DE PROCESSO COLETIVO E A IMPORTÂNCIA DAS AUDIÊNCIAS PÚBLICAS}

A Emenda Constitucional 45 instituiu a repercussão geral de questão constitucional como requisito de admissibilidade do recurso extraordinário, ressignificando a sistemática do presente recurso, que não mais fica adstrito à análise de questões exclusivamente individuais. A partir de 2004 o recorrente passou a ser obrigado a demonstrar a transcendência do caso concreto, ou seja, que o mesmo não se limita apenas aos interesses das partes que integram a relação processual originariamente constituída.

Nesse cenário, verifica-se que o objeto do recurso extraordinário atualmente versa sobre questões que vão além da individualidade das partes em juízo. A coletivização das pretensões recursais passa a ser o pressuposto para o julgamento do caso concreto. Os efeitos jurídicos do julgamento de mérito são vinculantes, erga omnes, transcendentes, verticais e horizontais. $\mathrm{O}$ processo assume, assim, o modelo coletivo, com uma teorização própria, já que a sistemática do processo individual não poderá ser transplantada para a análise das questões debatidas em juízo.

Pensar o recurso extraordinário na perspectiva do processo civil é retirar dos interessados o direito de participação na construção do provimento. É necessário compreender que o modelo participativo de processo coletivo democrático-constitucionalizado é a forma mais viável de assegurar a legitimidade jurídica da decisão final, para que o mesmo materialize a formação discursiva da vontade coletiva. Concentrar a decisão do caso concreto apenas nas mãos dos julgadores é uma forma de excluir as partes interessadas do debate processual da pretensão recursal.

O estudo do recurso extraordinário sob a ótica da processualidade democrática é uma forma de reconhecer que o modelo constitucional de processo coletivo garante a todos os interessados a oportunidade isomênica ${ }^{2}$ de construção discursiva do provimento final. É legitimar que todos aqueles afetados pelos efeitos do provimento integrem o espaço processual como legitimado ao debate amplo das questões controvertidas.

Nesse cenário, indaga-se: como procedimentalizar a participação de todos os interessados (difusos e coletivos) na construção do provimento de natureza coletiva, observando-se o principio da celeridade processual e duração razoável do processo? A resposta a tal indagação passa

2 Isomenia é a igualdade jurídica conferida às partes de interpretar, compreender e aplicar racionalmente o direito ao caso concreto. 
diretamente pelo entendimento da teoria das ações coletivas como ações temáticas, de autoria do jurista mineiro Vicente de Paula Maciel Júnior (2008, p. 32-58).

O processo coletivo no modelo participado e visto sob a ótica das ações temáticas, compreende a legitimação para agir a partir do objeto, não mais do sujeito. Será o objeto do recurso extraordinário o referencial utilizado como parâmetro para definir quais são os legitimados a participar do debate processual. Não pode o legislador definir aprioristicamente quais são os legitimados ao processo coletivo, haja vista que dessa forma elegerá um grupo de sujeitos pressupostamente legitimados, excluindo-se aqueles que sofrerão os efeitos do provimento final.

No momento em que o Supremo Tribunal Federal admite um recurso extraordinário deverá tornar público o seu objeto, concretizando tal publicidade através de todos os meios legítimos de comunicação, como veículos da imprensa (escrito, televisionado e rádios), redes sociais e demais ferramentas tecnológicas que venham a permitir que todos os interessados conheçam a pretensão recursal que diz respeito aos direitos que lhes pertencem. A partir daí deve-se oportunizar a realização de audiências públicas nas mais diversas localidades do país, com a finalidade de que todos os interessados (difusos e coletivos) possam externar seus posicionamentos quanto ao objeto do recurso.

A realização de audiências públicas é essencial para assegurar a democraticidade do provimento final, Nessas audiências os interessados poderão definir os temas que são pertinentes e coerentes com o objeto do recurso, vinculando-se cada qual ao grupo temático que seja mais pertinente com seus direitos. Após a definição dos grupos temáticos, cada representante adequado do seu respectivo grupo levará ao Supremo Tribunal Federal os temas levantados pelos seus interessados.

Antes do julgamento do mérito da pretensão recursal deverá ser realizada uma audiência pública no Supremo Tribunal Federal, momento em que cada representante adequado apresentará os temas propostos e definidos pelos seus interessados. Essa será a oportunidade que a coletividade terá de participar do debate meritório do julgamento do recurso extraordinário, garantindo-se a legitimidade democrática do provimento.

Após a realização da audiência pública no Supremo Tribunal Federal seus ministros julgarão o mérito do recurso extraordinário, momento em que deverão se manifestar juridicamente sobre cada tema debatido em juízo, justificando racionalmente porque acolheu ou deixou os argumentos apresentados por cada grupo temático.

Nessa proposta teórica apresentada é possível garantir a democraticidade na formação da vontade coletiva, retirando dos ministros a exclusividade na decisão de questões coletivas e oportunizando a todos os interessados o direito de debater, opinar, divergir, convergir e construir discursivamente o provimento final.

\section{CONSIDERAÇÕES FINAIS}

A procedimentalização atual do recurso extraordinário no Brasil estabelece que a 
repercussão geral de questão constitucional é considerada, nos termos disposto no artigo 102, $\S 3^{\circ}$ da Constituição de 1988, um requisito específico de admissibilidade. Ao recorrente incumbe demonstrar a relevância jurídica, social, política ou econômica da pretensão recursal; que a mesma transcende o objeto e os interesses das partes que originariamente constituíram a relação processual. Trata-se da necessidade de evidenciar que o objeto do presente recurso versa sobre questões de cunho metaindividual, ou seja, coletivo ou difuso.

Embora o legislador e a doutrina majoritária considerem a repercussão geral como um requisito de admissibilidade, verificou-se no presente trabalho que estamos diante de matéria de mérito processual. Considera-se mérito processual todas as questões de fato (provas) e de direito que integram pretensão deduzida em juízo. Sabe-se que o recurso extraordinário tem como objeto exclusivamente matéria de direito, haja vista que a função do Supremo Tribunal Federal é verificar a aplicabilidade do texto constitucional em questões que versam sobre direitos da coletividade.

Revisitar a natureza jurídica da repercussão geral de questão constitucional é demonstrar que se trata de juízo pré-meritório da pretensão recursal, não de questão meramente formal e indispensável à procedimentalização do recurso extraordinário. Ou seja, o recorrente deverá demonstrar que a matéria de direito alegada ultrapassa a individualização originária da pretensão deduzida. No momento em que tal questão é analisada pelo judiciário temos o enfrentamento inicial das questões de mérito que integram a pretensão recursal.

A transindividualização da pretensão recursal denota que o recurso extraordinário deverá ser pensado sob a égide do processo coletivo democrático. Utilizar o processo civil como referencial teórico do julgamento do mérito é concentrar o poder de decisão exclusivamente nas mãos dos julgadores, além de não permitir que os sujeitos afetados pelos efeitos erga omnes e vinculantes do provimento final participem discursivamente de sua construção.

O processo coletivo, na perspectiva da constitucionalidade democrática, é um lócus (espaço) que deverá oportunizar a todos os interessados o direito de debater os pontos controversos da demanda, além de participar dialeticamente da formação da vontade coletiva. Deve ser assegurado a todos os sujeitos o exercício da cidadania mediante a igual oportunidade jurídica de interpretação da norma (isomenia); direito de opinar, convergir, divergir e dialogar sobre as questões de direito que integram o objeto do processo. É a forma de superar a autocracia jurisdicional, retirando dos julgadores a exclusividade e discricionariedade no julgamento solitário de questões cujos efeitos jurídicos estendem-se a um número indeterminado de pessoas.

No momento em que o legislador brasileiro condicionou o julgamento do mérito do recurso extraordinário à demonstração da repercussão geral de questão constitucional certamente o elevou à categoria de processo coletivo. Por isso, deve-se garantir a legitimidade jurídico-democrática do provimento final mediante a oportunidade de construção participada do mérito processual por todos os sujeitos interessados.

A aplicabilidade da teoria das ações coletivas como ações temáticas; a publicização do objeto do recurso extraordinário pelos meios de comunicação físicos e eletrônicos; a realização de audiências públicas em todo o Brasil que viabilize o direito dos interessados apresentarem 
temas pertinentes com o objeto do recurso; a realização de audiência pública no Supremo Tribunal Federal, oportunizando aos representantes adequados o direito de debater os temas apresentados e relacionados com o objeto do recurso. A obrigatoriedade dos ministros do STF se manifestarem juridicamente sobre todos os temas suscitados por cada grupo temático, justificando porque acolheu ou deixou de acolher são algumas ferramentas e propostas apresentadas nessa pesquisa para garantir a legitimidade democrático-participativa do provimento final, além de superar o solipsismo e o decisionismo judicial.

Nesse sentido, conclui-se que o recurso extraordinário é um modelo de processo coletivo democrático-participativo, haja vista que se trata de espaço onde são debatidas pretensões de cunho metaindividual, cujos efeitos jurídicos do provimento se estendem a todos os interessados difusos e coletivos vinculados ao objeto do recurso. Reconhecer a repercussão geral de questão constitucional apenas como um requisito de admissibilidade, cuja análise do mérito processual do recurso proposto fica restrito aos ministros do Supremo Tribunal Federal, é retirar dos destinatários do provimento a possibilidade de participar de sua construção.

Compreender a repercussão geral de questão constitucional como juízo de mérito é uma forma de ampliar o espaço processual de debate das questões que integram a pretensão recursal, garantindo-se a democraticidade do provimento mediante a participação de todos os interessados por meio das audiências públicas.

\section{REFERÊNCIAS}

BARBOSA, Rafael Vinheiro Monteiro. Reflexos da repercussão geral no sistema de interposição conjunta do recurso extraordinário e do recurso especial e a sugestão para o problema. Revista de Processo, São Paulo, n. 158. p. 161-188, abr. 2008.

BORGES, Marcos Afonso. O recurso extraordinário e a repercussão geral. Academia Brasileira de Letras Jurídicas, Rio de Janeiro, n.32/33, p. 111-119, c2012. Disponível em: http://www.ablj.org.br/revistas/revista32e33/revista32e 33\%20\%20MARCOS\%20 AFONSO\%20BORGES\%20-\%20O\%20recurso\%20extraordin $\% \mathrm{C} 3 \% \mathrm{~A} 1$ rio $\% 20 \mathrm{e} \% 20 \mathrm{a} \% 20$ Repercuss\%C3\%A3o\%20geral.pdf. Acesso em: 25 jan. 2017.

BRASIL. [Constituição (1988)]. Constituição da República Federativa do Brasil de 1988. Brasília, DF: Presidência da República, [2016]. Disponível em: http://www.planalto.gov.br/ ccivil_03/constituicao/constituicao.htm. Acesso em: 18 mar. 2018.

BRASIL. Lei $\mathbf{n}^{\circ}$ 11.418, de 19 de Dezembro de 2006. Acrescenta a Lei $n^{\circ} 5.869$, de 11 de janeiro de 1973 - Código de Processo Civil, dispositivos que regulamentam o $\S 3^{\circ}$ do art. 102 da Constituição Federal. Brasília, DF: Presidência da República, 2006. Disponível em: http://www. planalto.gov.br/ccivil_03/_Ato20042006/2006/Lei/L11418.htm. Acesso em: 18 mar. 2018.

CAPPELLETTI, Mauro. Juízes legisladores? Tradução Carlos Alberto Álvaro de Oliveira. Porto Alegre: Sérgio Antônio Fabris Editor, 1993.

DIAS, Ronaldo Bretas de Carvalho. Processo constitucional e estado democrático de direito. Belo Horizonte: Del Rey, 2010. 
FERREIRA, Juliana Maria Matos. Teoria do processo coletivo no modelo participativo. Belo Horizonte: D'Plácido, 2016.

FREITAS, Gabriela Oliveira. A uniformização de jurisprudência no Estado Democrático de Direito. Rio de Janeiro: Lumen Juris, 2014. (Coleção Estudos da Escola Mineira de Processo, v.4).

GRESTA, Roberta Maia. Introdução aos fundamentos da processualidade democrática. Rio de Janeiro: Lumen Juris, 2014. (Coleção Estudos da Escola Mineira de Processo, v. 1).

KOSZUOSKI, Adriana; PENACHIONI, Bruna Thaisa Dias. Repercussão geral no recurso extraordinário. Revista Jurídica da Universidade de Cuiabá, Cuiabá, v. 12, n. 2, 2010. Disponível em: file://C:/Documents\%20and\%20Settings/pc/Meus\%20documentos/ Downloads/180-672-1-PB.pdf. Acesso em: 26 jan. 2017.

LEAL, André. O contraditório e a fundamentação das decisões no direito processual democrático. Belo Horizonte: Mandamentos, 2002a.

LEAL, Rosemiro Pereira. Teoria processual da decisão jurídica. São Paulo: Landy, 2002b.

LEAL, Rosemiro Pereira. Teoria geral do processo. 8. ed. Rio de Janeiro: Forense, 2009.

MACIEL JUNIOR, Vicente de Paula. Teoria das ações coletivas: as ações coletivas como ações temáticas. São Paulo: Ltr, 2008.

OZAKI, Veridiana Tonzar Ristori. Repercussão geral no recurso extraordinário. Caderno de Pesquisa, Franca, v.1, n. 1, 2010. Disponível em:

http://ojs.franca.unesp.br/ojs/index.php/cardernopesquisa/article/view/214/260. Acesso em: 17 jan. 2017.

PAOLINELLI, Camilla Mattos. O ônus da prova no processo democrático. Rio de Janeiro: Lumen Juris, 2014. (Coleção Estudos da Escola Mineira de Processo, v.3).

PRADO, Lídia Reis de Almeida. O juiz e a emoção: aspectos da lógica da decisão judicial. 5. ed. Campinas: Millennium, 2010.

STRECK, Lenio Luiz. O que é isto: decido conforme minha consciência? 3. ed. Porto Alegre: Livraria do Advogado, 2012.

WAMBIER, Luiz Rodrigues; TALAMINI, Eduardo. Curso avançado de processo civil. 11 .ed. rev.,atual. e ampl. São Paulo: Revista dos Tribunais, 2010.

Como citar: COSTA, Fabrício Veiga; SILVA, Alex Matoso; SILVA, Rosemary Cipriano da. Recurso extraordinário como modelo de processo coletivo. Revista do Direito Público, Londrina, v. 14, n. 2, p. 91-108, ago. 2019. DOI: 10.5433/24157-108104-1.2019v14n2p. 91. ISSN: 1980$511 \mathrm{X}$ 
Recebido em: 22/11/2017.

Aprovado em: 01/07/2019. 